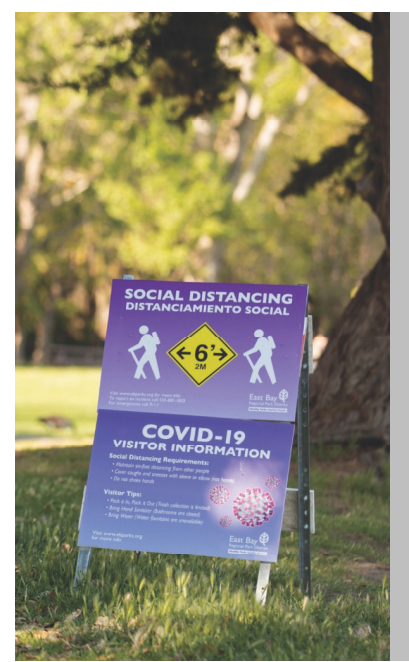

\title{
URBAN PARKS AND PROTECTED AREAS: ON THE FRONT LINES OF A PANDEMIC
}

\author{
Greg Moore ${ }^{1}$ and Jo Hopkins ${ }^{2}$ \\ mooregreg@comcast.net; jo.hopkins@parks.vic.gov.au \\ ${ }^{1}$ Golden Gate National Parks Conservancy, California, USA \\ ${ }^{2}$ IUCN WCPA Health and Well-being Specialist Group, Australia
}

\section{ABSTRACT}

Urban parks and protected areas are vital to the health and well-being of millions of urban dwellers across the globe. The COVID-19 pandemic has put this connection into urgent focus in major cities where most of the world's population live. Managers of urban parks and protected areas (green spaces in or at the edge of larger urban population centres) have been at the forefront of this international public health crisis since its onset - facing its challenges and impacts, adopting and adapting park responses, and testing new approaches. To inform this article, the experiences of urban parks and protected areas in 11 major cities in 10 different countries were gathered in surveys. The findings show that urban parks were closed and then often overwhelmed on reopening, and that managers faced novel and sometimes unmanageable situations. However, most were responsive and nimble, engaged with public health officials, dealt with new levels of visitation and new visitors, implemented innovative management practices and garnered lessons for the future. Huge challenges remain but there are hopeful signs of renewed public awareness and support for the critical role that nature and the outdoors play in the liveability and health of cities.

Key words: COVID-19, Health, Impact and Challenges, Snapshots, Innovations and Lessons

\section{CONTEXT AND PURPOSE OF ARTICLE}

Since the outbreak of COVID-19 in early 2020, park managers in our cities have been thrust into an unfamiliar world. Urban parks and protected areas exist in and near major cities where the virus has spread and often spiked. Because the virus is considerably less contagious in the outdoors than indoors (Nishiura et al., 2020), parks are under pressure to respond to the pandemic and provide their recreational, health, mental well-being and community benefits to larger numbers of people.

The questions we have tried to answer in this article are: what have been the impacts and challenges for urban parks and protected areas? How have park managers responded? Has the pandemic required new partnerships and innovations? And what are the lessons or hopes for the future?

PARKS AND HEALTH: NOT A NEW CONNECTION One thing is clear: the pandemic has intensified the connection between public health and public parks - a connection that began two decades ago with the launch of the Healthy Parks Healthy People movement. Initially created by Parks Victoria (Australia) in 2000, Healthy Parks Healthy People is an approach to managing parks and protected areas that has grown into a global movement. It recognises that people need access to parks and green spaces for the health benefits that nature provides; and that the health and well-being of people and societies depend on healthy natural environments. Over the years, International Union for Conservation of Nature (IUCN) has advanced this connection between human and natural health, which was highlighted at its World Parks Congress in 2014. Applying this approach to land management offers great potential to deliver a range of positive health outcomes as society recovers from the COVID-19 pandemic.

A 2015 review by Deakin University (Townsend et al., 2015) found parks provide significant physical, emotional and spiritual benefits to all age groups as well as fostering social connections which contribute to community cohesion. Now, in 2021, the pandemic has made these benefits even more evident and tangible to park managers and city residents across the globe. 


\section{METHODS}

The relatively short timeframe since the pandemic's inception did not easily allow for comprehensive research. Nonetheless, we have gathered a range of insights and perspectives from managers, consultants and experts from around the world, who have been engaged with urban parks and protected areas during the pandemic.

To understand the effects of COVID-19, a survey form was provided to urban parks and protected and conserved area managers, consultants and experts. The parks varied in size, urban proximity, management entity, visitation, economic context, community demographics and level of COVID-19 cases in surrounding communities. Four key topic areas were explored: impacts, challenges, innovations and future lessons. Direct conversations, interviews and email correspondence with attached materials and reports supplemented the form. We also reviewed research papers, articles, reports and media items about urban parks, public health and the pandemic.

\section{IMPACT AND CHALLENGES}

In March 2020, urban parks and protected areas found themselves on the front lines of a global pandemic. Park managers had to quickly pivot from their primary conservation and recreational mission to focus on ensuring the safety of park staff and visitors during a pandemic. Few parks had prepared for such a global emergency. Many parks struggled to manage visitation during COVID-19, especially with shortfalls in funding and park revenue caused by the pandemic. Some preliminary research by the NATURVATION ${ }^{1}$ project (Almassy et al., 2020) had suggested that "COVID-19 brought additional pressure on urban parks that local authorities managing them were not always able to absorb". To respond, most park managers had to seek expert advice outside of their normal experience and from beyond their borders. Yet quick decision-making was required.

For those parks contacted for this article, the most immediate impact was the uncertainty of how to respond to the pandemic and raising questions as to who was authorised to make COVID-related decisions on behalf of parks. Most parks and cities took the cautious approach, closing parks and their facilities until the level of threat could be assessed, jurisdictional issues were resolved and consultation with public health officials could occur. While there was wide variation (one large urban park system re-opened within 24 hours; another national park in a major city was closed for nine months), most urban parks and protected areas opened gradually, achieving significant reopening within four to six months.

Other significant challenges, brought to light by the snapshots in this article, included:

- Excessive demand for the outdoors, parks and open space. Strong demand from the public to have access to parks put managers under pressure to address the safety, resource protection, logistical and political questions associated with deciding when and how to open them. Most parks that were opened faced significant overcrowding. As a result, parking areas, trails and viewing points were used beyond capacity, staff resources were insufficient for maintenance and patrol, and visitors were unable to adequately social distance.

- Rapidly changing conditions. The changing levels of COVID-19 infection, and the public health guidelines required to respond to these changes, resulted in continually fluctuating conditions. Park managers had to adjust COVID-19 alert levels, with consequential impacts on visitor use of park grounds and facilities.

- Making the parks safe. Where parks remained open, or re-opened, managers had to quickly develop safety protocols for staff and visitors, produce signage and public communication campaigns to make those standards clear, and determine how to enforce social distancing and face mask standards.

- Poor visitor compliance. Issues with compliance with COVID-related protocols and other park rules arose most often on crowded urban beaches, in parks with low-capacity destinations that were highly sought-after locations (such as scenic viewing points, outdoor pavilions or picnic areas), and in parks with multiple access points.

- Reduced staffing levels. A range of impacts resulted from staff members being directly affected by COVID -19 as well as a decline in revenue to pay for staff.

- Forecasted funding declines. Parks with government funding models tended to fare better than parks with revenue-generating 'enterprise' models. However, even parks with more stable government funding are forecasting future funding declines as the full economic impacts of the pandemic are felt.

But while many problems were revealed, we also identified much innovation and indeed causes for optimism. We discuss these towards the end of the paper. At a time of pessimism, it is important to report that our survey also gave grounds for hope. 


\section{SNAPSHOTS: URBAN PARKS, PROTECTED AREAS, AND THE PANDEMIC}

Urban park and protected area managers, consultants and experts have emphasised that the pandemic is highly dynamic and that park managers have had to respond to fluctuating conditions. Recognising the changing course of the pandemic, we have gathered 'snapshots' from a number of urban parks and protected areas at one point in time - in October 2020 about seven months into the pandemic (Table 1: Participating parks and protected areas). In selecting these case studies, we wanted to include parks that varied in terms of their proximity to cities, size, visitor numbers, exposure to COVID-19, management types, geography, demographics and local economies, and we needed willing participants. Many of these factors are summarised in Table 1.

\section{Snapshot 1: Vancouver, British Columbia, Canada - City, Regional and Provincial Parks²} The healing power of parks: now and forever

"As we speak of plans that will chart our way to economic recovery and health through COVID-19, included in these must be funding and policy to safeguard and grow our

Table 1. Participating parks and protected areas

\begin{tabular}{|c|c|c|c|c|c|c|}
\hline $\begin{array}{l}\text { SNAP- } \\
\text { SHOT }\end{array}$ & $\begin{array}{l}\text { URBAN } \\
\text { LOCATION }^{1}\end{array}$ & POPULATION & $\begin{array}{l}\text { PARK OR } \\
\text { PROTECTED } \\
\text { AREA(S) }\end{array}$ & $\begin{array}{c}\text { SIZE } \\
\text { (hectares) }\end{array}$ & $\begin{array}{l}\text { ANNUAL } \\
\text { VISITATION } \\
\text { (Approximate) }\end{array}$ & $\begin{array}{l}\text { MANAGEMENT } \\
\text { ENTITYIENTITIES }\end{array}$ \\
\hline 1 & $\begin{array}{l}\text { VANCOUVER } \\
\text { METRO, British } \\
\text { Columbia, } \\
\text { Canada }\end{array}$ & 2.5 million & $\begin{array}{l}\text { Vancouver } \\
\text { municipal, regional } \\
\text { and provincial } \\
\text { parks }\end{array}$ & $\begin{array}{c}84,000 \\
\text { hectares }\end{array}$ & 33 million & $\begin{array}{l}\text { Municipal, Regional and } \\
\text { Provincial Park Agencies }\end{array}$ \\
\hline 2 & $\begin{array}{l}\text { SANTIAGO } \\
\text { METRO, Chile }\end{array}$ & 7 million & $\begin{array}{l}\text { Metropolitan Park } \\
\text { of Santiago }\end{array}$ & $\begin{array}{l}700 \\
\text { hectares }\end{array}$ & 6 million & $\begin{array}{l}\text { Parque Metropolitano de } \\
\text { Santiago (Parquemet) }\end{array}$ \\
\hline 3 & $\begin{array}{l}\text { HONG KONG } \\
\text { Special } \\
\text { Administrative } \\
\text { Region, China }\end{array}$ & 7.5 million & $\begin{array}{l}\text { Hong Kong } \\
\text { Country Parks and } \\
\text { Protected Areas }\end{array}$ & $\begin{array}{l}110,800 \\
\text { hectares }\end{array}$ & 12 million & $\begin{array}{l}\text { Country Parks and } \\
\text { Protected Areas in Hong } \\
\text { Kong, Special Administrative } \\
\text { Region }\end{array}$ \\
\hline 4 & $\begin{array}{l}\text { KAOHSIUNG, } \\
\text { Taiwan }\end{array}$ & 2.7 million & $\begin{array}{l}\text { Shoushan National } \\
\text { Nature Park }\end{array}$ & $\begin{array}{c}1,123 \\
\text { hectares }\end{array}$ & 2.6 million & $\begin{array}{l}\text { National Nature Park } \\
\text { Headquarters }\end{array}$ \\
\hline \multirow{2}{*}{$5^{3}$} & QUITO, Ecuador & 1.8 million & $\begin{array}{l}\text { AlER Pichincha- } \\
\text { Atacazo }\end{array}$ & $\begin{array}{c}9,932 \\
\text { hectares }\end{array}$ & $\sim 2$ million & $\begin{array}{l}\text { Various municipal and } \\
\text { federal entities }\end{array}$ \\
\hline & $\begin{array}{l}\text { RIO DE } \\
\text { JANEIRO, Brazil }\end{array}$ & 13 million & $\begin{array}{l}\text { Tijuca } \\
\text { National Park }\end{array}$ & $\begin{array}{c}3350 \\
\text { hectares }\end{array}$ & Not available & $\begin{array}{l}\text { Chico Mendes Institute for } \\
\text { Biodiversity Conservation }\end{array}$ \\
\hline 6 & $\begin{array}{l}\text { LIBREVILLE, } \\
\text { Gabon }\end{array}$ & 700,000 & $\begin{array}{l}\text { Arboretum } \\
\text { Rapando Walker }\end{array}$ & $\begin{array}{c}6,747 \\
\text { hectares }\end{array}$ & 11,500 & National Park Agency \\
\hline 7 & $\begin{array}{l}\text { MUMBAI, } \\
\text { India }\end{array}$ & 16 million & $\begin{array}{l}\text { Sanjay Gandhi } \\
\text { National Park }\end{array}$ & $\begin{array}{c}10,000 \\
\text { hectares }\end{array}$ & 1.5 million & $\begin{array}{l}\text { Ministry of Environment, } \\
\text { Forest and } \\
\text { Climate Change }\end{array}$ \\
\hline 8 & $\begin{array}{l}\text { AUCKLAND, } \\
\text { New Zealand }\end{array}$ & 4 million & Cornwall Park & $\begin{array}{c}172 \\
\text { hectares }\end{array}$ & 4 million & Cornwall Park Trust \\
\hline \multirow[b]{2}{*}{$9^{4}$} & $\begin{array}{l}\text { ALAMEDA and } \\
\text { CONTRA } \\
\text { COSTA } \\
\text { COUNTY, } \\
\text { California, USA }\end{array}$ & 2.8 million & $\begin{array}{l}\text { East Bay Regional } \\
\text { Park District }\end{array}$ & $\begin{array}{l}52,609 \\
\text { hectares }\end{array}$ & 25 million & $\begin{array}{l}\text { East Bay Regional } \\
\text { Park District }\end{array}$ \\
\hline & $\begin{array}{l}\text { LOS ANGELES } \\
\text { and VENTURA } \\
\text { COUNTY, } \\
\text { California, USA }\end{array}$ & 11 million & $\begin{array}{l}\text { Santa Monica } \\
\text { Mountains (SMM) } \\
\text { Conservancy zone } \\
\text { SMM National } \\
\text { Recreation Area }\end{array}$ & $\begin{array}{c}297,000 \\
\text { hectares } \\
62,726 \\
\text { hectares }\end{array}$ & $\begin{array}{c}10 \text { million } \\
\text { (about } 30 \\
\text { million with } \\
\text { beaches) }\end{array}$ & $\begin{array}{l}\text { US National Park Service, } \\
\text { Santa Monica Mountains } \\
\text { Conservancy, and } \\
\text { California State Parks }\end{array}$ \\
\hline \multicolumn{7}{|c|}{$\begin{array}{l}\text { 1URBAN LOCATION: The individual parks and park systems in this survey vary in their proximity to cities - from within a city or metro area to being within a } \\
60 \mathrm{~km} \text { radius of an urban centre. } \\
{ }^{2} \text { ANNUAL VISITATION: Some parks have actual counts; others are a mix of counts, sampling and estimates based on the park's physical characteristics and } \\
\text { visitor access points. While data may not always have been collected on a strictly comparable basis, they indicate the general magnitude and varying scale } \\
\text { of visitation to the parks. These visitation counts and estimates are pre-COVID. } \\
{ }^{3} \text { SNAPSHOT 5: The information for this Snapshot came from a park expert deeply knowledgeable about parks in both countries, which faced simila } \\
\text { situations with the pandemic; therefore, these two cities and park areas were combined. } \\
{ }^{4} \text { SNAPSHOT 9: Because of similar context in the State of California, these two large park systems were combined into one Snapshot. }\end{array}$} \\
\hline
\end{tabular}


parks and urban green spaces - for this is where we will instinctively go to heal and stay healthy when the next crisis, personal or global, comes."

Dr Melissa Lem, Director, Park Prescriptions, British Columbia Parks Foundation

Vancouver Parks: A wide array of city, regional and provincial parks - from downtown parks to large natural protected and conserved areas within 60 kilometres of the city centre.

Impacts and challenges: When COVID-19 reached British Columbia in March 2020, many parks and park facilities closed to the public. Since then, a major impact was the increased demand for the outdoors, parks and open spaces. Visitation levels increased by over 40 per cent, with some parks experiencing 85 per cent increases in visitation over the same period in 2019. At the same time, car access increased as public transport use declined due to safety concerns, creating problems for the parks and adjacent communities.

Overcrowding became a problem at many park sites. Booking websites for park programmes, campgrounds and services were overwhelmed and many crashed. The parks experienced their highest ever demand for camping sites. Camping and hiking occurred in undesignated areas or without proper permits. New populations of visitors came to the parks - often people lacking experience in 'leave no trace' visits: for example, some people who were unfamiliar with bear-proof trash cans just left garbage on the ground.

Innovations and lessons: Faced with common challenges, park agencies instituted more planning and communication among their jurisdictions, as well as with public health officials; and with the public about effectively ensuring visitor safety while making the outdoors accessible during a pandemic. On the positive side, the public's increased demand and use of the parks encouraged action and innovation. Thus, public health officials recognised the value of people getting outdoors; and park agencies took measures to provide safe access, including one-way trails, social distancing, crowding controls, and using parks for childcare and public health needs.

The British Columbia Parks Foundation championed an innovative, experimental online portal which gave the public real-time information about park visitation levels so that people could better plan a safe time to visit. Based on its success, the Foundation is exploring a more ambitious technology connection, Discover Parks, which will keep park visitors and supporters more easily connected to their parks, aware of park needs, and involved as advocates, volunteers and donors.
Snapshot 2: Santiago, Chile - Metropolitan Park of Santiago (Parque Metropolitano de Santiago Parquemet)3

Together We Take Care of Ourselves

\begin{abstract}
"We see the happy faces of the families who are visiting our parks after more than five months when many of these public spaces were closed due to the confinement of COVID-19. We are motivated, with more energy and passion than ever, to achieve our crucial mission to deliver happiness to people by connecting them with parks, nature, the outdoors and one another."
\end{abstract}

Martín Andrade Ruiz-Tagle, Director, Parque Metropolitano de Santiago

Metropolitan Park of Santiago: A large 'green lung' of parks, forests and gardens providing nature, recreation and environmental education within Santiago Metro.

Impacts and challenges: Responding to the pandemic, Parquemet initially closed many of its park areas, while working quickly and effectively to establish safe visitor capacity levels for their parks.

Innovations and lessons: Parquemet developed an innovative system of web-based information and QR codes that allowed people to see the number of visitors in each park in real time. Called Juntosdenuevo (Together Again), this application is designed to help visitors "maintain social distancing outside your home, avoiding crowds in public spaces" under the motto of "Together We Take Care of Ourselves". People can find the park to visit and "book their space" on the site or with a QR code on the phone. If park quotas are full, the system places people in a virtual queue, notifying them when it is their turn to visit.

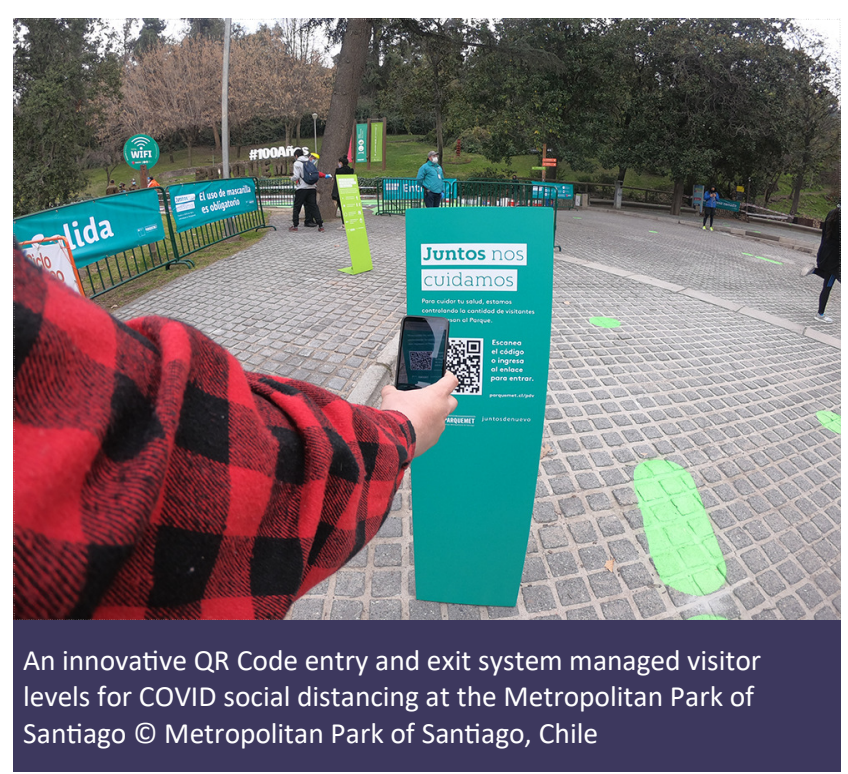


COVID-19 has made people more aware of equity issues in the public's access to green spaces and the outdoors. There are significant inequalities between rich and poor areas; some Santiago neighbourhoods have 20 square metres of park area per person, while others have less than 3 square metres.

Parquemet sponsored a beautiful artistic display that welcomed Santiago residents back to parks after the COVID-19 closure. At the entrance to the Metropolitan Park of Santiago, a Chilean artist created a walkway mural covering more than 1,000 square metres. In addition, Parquemet installed colourful, artistic demarcations to support social distancing in the park. These efforts give a message to cities, urban parks and protected areas - indeed to the world at large: Together We Take Care of Ourselves.

\section{Snapshot 3: Hong Kong Special Administrative Region, China - Hong Kong Country Parks and Protected Areas 4}

When parks become refuges, their importance grows.

\begin{abstract}
"Protected areas are refuges for citizens in times of a pandemic. Hong Kong is not unfamiliar with pandemics, particularly the SARS epidemic in 2003-2004. That epidemic resulted in improvements to park programming and management, increased public interest in nearby ecology, and the provision of university courses on sustainable tourism and local heritage. The COVID-19 pandemic will foster new opportunities to enhance parks and expand recognition of the value and importance of urban protected areas and open spaces."
\end{abstract}

Dr Wong Fook-yee, Adjunct Professor, Geography and Resource Management Department, Chinese University of Hong Kong

\section{Hong Kong Country Parks and Protected Areas:} 24 country parks for conservation, recreation and outdoor education and 22 special areas for nature conservation within about 50 kilometres from the city of Hong Kong.

Impacts and challenges: COVID-19 affected Hong Kong most seriously from March to May and from mid-June to early September 2020. During these periods, barbecue sites, camping areas and visitor centres were closed to the public. Generally, other areas of the country parks have remained open and become a refuge for people during the pandemic. Overall park visitation increased, along with various impacts on the parks. Many visitors are new to the parks and unfamiliar with various park regulations. This resulted in litter and in some cases careless fire handling caused hillside fires. The park management and associated NGOs organised staff and volunteers to pick up waste and alert visitors to the importance of keeping the countryside clean.
Innovations and lessons: Park managers encouraged visitors to use their own water bottles and established more than 20 water refilling stations within park lands. To support businesses inside country parks, including refreshment kiosks, cafeterias and souvenir shops, rents were reduced by 50 per cent for a six-month period.

In marine areas, where sea traffic has fallen during the pandemic, more sightings of local Chinese White Dolphins were reported. The absence of visitors provided a respite for wildlife in ecologically sensitive sites for butterflies and birds, such as Mai Po Nature Reserve.

An international conference for park managers, designed to exchange experiences and lessons learned during the pandemic, could be valuable, not only for the managers, but for health experts and other government officials charged with responding to future public health crises.

\section{Snapshot 4: Kaohsiung City, Taiwan - Shoushan National Nature Park5}

Open to visitors and to enhanced awareness of nature and health

\begin{abstract}
"The successful experience of the Taiwanese government in epidemic prevention will increase the public's awareness of the connection between parks and public health, the willingness of visitors to cooperate with the resource protection regulations of the park, and the openness to efforts to manage park visitation levels that reduce overcrowding and its impacts."
\end{abstract}

Lih-Der Ho, Professor, National Kaohsiung Normal University, Taiwan

Shoushan National Nature Park: A rare green space of seasonal tropical forest, limestone caves, endemic wildlife and archaeological sites about 13 kilometres from the city of Kaohsiung.

Impacts and challenges: Responding to COVID-19, park managers took immediate action for the safety of park visitors. They halved the number of available car parking spaces. Access was curtailed to indoor facilities, guided tours and on-site interpretation. The park developed online activities and communications to encourage safe visitor behaviour and enhance interpretation.

Visitors entering indoor facilities were required to follow epidemic prevention measures, such as measuring body temperature, wearing masks and filling in a personal information log. The park posted epidemic prevention notices indicating safe visitor capacity at park gathering areas. Even so, many visitors failed to maintain this 
social distancing at first but, with more promotion, the situation improved significantly. Some visitors were unhappy about the measures, especially as the park's popularity made it difficult to maintain social distancing at key outdoor pavilions.

Innovations and lessons: Major innovations include social media campaigns to introduce and promote park resources, so reducing the health risk caused by gatherings of tourists. The park visitor centre offered online interactive activities to encourage visitors to check in and take photos at designated places in the park, and then upload photos to a Facebook fan page. These social media campaigns allowed tourists to go to the park separately and avoid gatherings. The park also organised 'flash events', replacing the original longerterm activities with short-term ones to reduce contact time with the public.

As a protected area in Taiwan, Shoushan National Nature Park has benefitted from the effective containment of COVID-19 on this island of 23 million people. Management responses were focused on the safety and number of visitors rather than on closing parks. The pandemic activated a valuable dialogue and engagement between park and visitors - a positive platform for the future.

\section{Snapshot 5: Quito, Ecuador and Rio de Janeiro, Brazil - Urban Parks and Protected Areas ${ }^{6}$ \\ Future challenges and inequities}

\begin{abstract}
"The future poses many challenges for urban parks and protected areas in countries struggling economically. During an economic crisis resulting from COVID-19, the parks are affected disproportionally with reductions of government funding and other economic activity. Additionally, a divide exists between parks near wealthier and poorer communities. This inequity will affect the ability of the parks to be resilient after the pandemic."
\end{abstract}

Pedro da Cunha e Menezes, Member, IUCN Urban Conservation Strategies Specialist Group (currently a Brazilian Diplomat in Ecuador and former Manager of Tijuca National Park, Rio de Janeiro, Brazil)

Ecuador and Brazil Urban Parks: Large areas of urban parks, natural landscapes, protected and conserved areas and natural areas of special intervention and recovery (AIER) near the major city of Quito, Ecuador (35-50 kilometres) and Tijuca National Park near Rio de Janeiro, Brazil (17 kilometres).

Impacts and challenges: Both Ecuador and Brazil took a rapid and strict approach by closing parks and protected areas in March 2020. Most parks remained

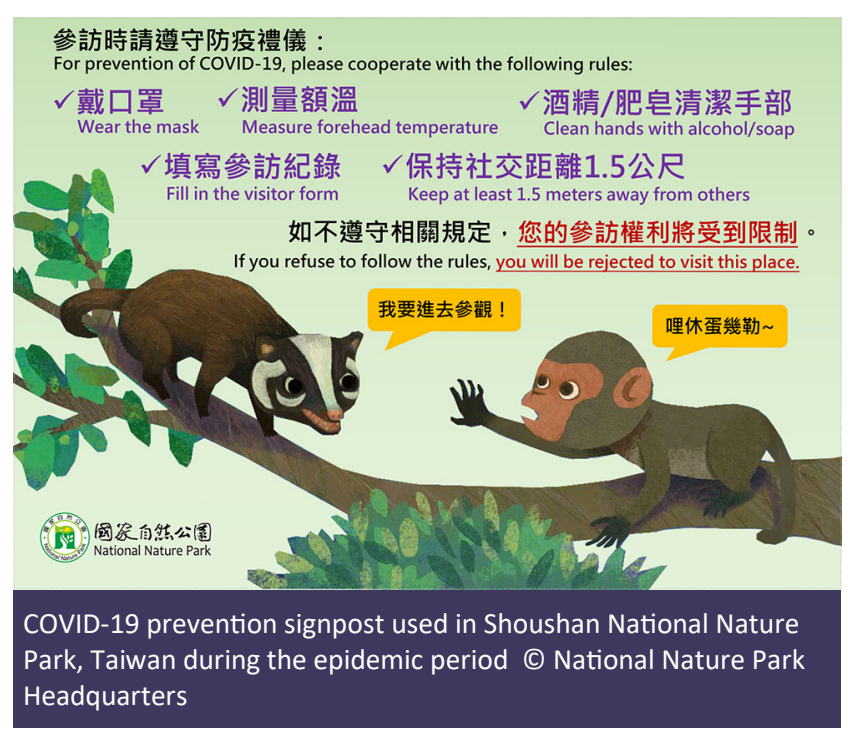

fully closed until re-opening in August 2020 with restrictions including social distancing, mask requirements and bans on gatherings. Some highly popular visitor features, such as scenic viewing points, remain closed.

Park managers faced many challenges because of COVID-19. The pandemic produced an increased demand for and visitation to parks. Once parks were open, people were eager to return to nature. Because other leisure options were limited or unavailable, there was more pressure on parks. Visitation levels were higher than before the pandemic, placing a burden on park management, especially parks with limited ranger presence.

Many new visitors were unaccustomed to nature-based parks and inexperienced in hiking, trail use and other nature-based activities. As a result, visitor behaviour, crowding and compliance were problematic. Most urban parks and protected areas have multiple entry points not a single, patrolled entrance gate. This made controlling visitor numbers and supervising visitor behaviour an added challenge.

Park closures led to reduced income from concessions and tourism, adversely affecting local community businesses as well as funding for the parks.

Innovation and lessons: Although innovation in the face of these challenges is desirable, the situation has been too unpredictable and under-resourced for the development of management innovations. Park managers were fortunate if they could just keep up with things on a day-to-day basis. Future challenges may be long-lasting and daunting, with a significant and longterm reduction of funding and staffing of park areas. 


\section{Snapshot 6: Libreville, Gabon - Arboretum Raponda Walker7}

\section{New wildlife and new visitors}

\begin{abstract}
"When the complete lockdown concluded, the youth of Libreville experienced a new need and desire to discover nature. With the increase of youth and Gabonese urban residents visiting Arboretum Raponda Walker, we are hopeful that beyond COVID-19, the Gabon residents especially youth will invest more in nature protection for future generations."
\end{abstract}

Andrea Minkwe, Manager of Arboretum Raponda Walker protected area

The Arboretum Raponda Walker (ARW): Tropical rainforest managed for protection, restoration and the development of leisure activities, tourism, science and education, located just over 25 kilometres from the capital city of Libreville.

Impacts and challenges: Although the ARW did not immediately put measures in place to combat COVID19, the national government closed the park to all visitors for about four months between March and June 2020, leading to a complete halt in ecotourism activity.

Innovations and lessons: In preparation for reopening, ARW widened visitor pathways to maintain social distancing between visitors walking in the forest. Since the modest resumption of park visitation, some visitors have had encounters with wildlife not frequently seen before, such as Sitatunga (antelope) and Forest Turtles, such species having moved into new areas of the park in the absence of visitors.

More Gabonese have been attracted to the site, especially young people. This has required improvements, including opening new picnic areas, increased visitor reception capacity, adjustments to staff working hours, more orientation and information panels, an increase in the number of eco-guides and the creation of car parking areas.

\section{Snaphot 7: Mumbai, India - Sanjay Gandhi National Park 8}

A simple walk in the park critical to urban dwellers

\begin{abstract}
"The future of the park is a key to our prosperity. COVID19 has heightened awareness that nature must be in balance with our urban communities. The forest needs better protection and vigilant monitoring. It is a critical national asset when it comes to exposing and engaging people with the natural world."
\end{abstract}

Shardul Bajikar, consultant and naturalist associated with Sanjay Gandhi National Park

Sanjay Gandhi National Park: A forest of rich biodiversity with over 35 species of mammals, 250 species of birds and 1,300 species of plants in the heart of Mumbai City.

Impact and challenges: The government closed the park in March 2020, at the onset of the pandemic. Though the closure remained in place during the survey period of this article, plans are being made for modest levels of public access to the park. The major impacts of COVID19 result from the lack of any visitors to this park. Daily revenue through ticket sales fell by about 200,000 INR (about US\$ 2,700). After the initial phase of lockdown, local communities of people who walk in the park (averaging 3,00o walkers daily) called for access to be re -established. By early October, the park was planning to re-open to walkers.

The pandemic also produced effects inside the park. Some park staff and people living inside the park contracted COVID-19; due to these outbreaks, various small settlements inside the park were designated as COVID "containment zones" by the municipal and health authorities to help prevent the pandemic's spread.

Innovations and lessons: With access to the park closed, park authorities developed educational films about the forest and the various protection initiatives and interventions. Their films on the park's biodiversity were aired on social media platforms. Some live Instagram sessions highlighted researchers working in the park, raising public interest and engagement.

Using this platform, the park ran a 65-day series of posts about the lockdown, social distancing and personal safety, pointing out how some wild species also employ these survival strategies. This social media effort resonated: there were more than 600,000 views and 200,000 people responded to the campaign, during which the park Facebook page gained 12,500 new followers. Leading newspapers also featured and relayed this campaign.

The pandemic has raised questions about the high visitation levels at the park. Many believe that the current high number of visitors is not in the best interests of the forest. The pandemic presents an opening for policy makers to reduce this burden and convert the park into a high-quality ecotourism experience.

\section{Snapshot 8: Auckland, New Zealand - Cornwall Park9}

Temporary measures test future possibilities

"We remain optimistic about our future with summer ahead and the park's visitor numbers increasing. The park 
has been a real strength in the community with many local people enjoying the benefits that a vast open space offers, even more essential in a time of stress and public concern."

Michael Ayrton, Park Director, Cornwall Park Trust Board

Cornwall Park: An urban oasis rich with history, nature and farm-life including 8,00o trees, numerous gardens and habitat for wildlife within the city of Auckland.

Impacts and challenges: With the arrival of COVID-19, the park management immediately developed safety plans for park staff and visitors, which responded to 'alert levels' from the New Zealand Ministry of Health. The Trust encouraged park visitors to follow physical distancing guidance; however, with limited staff and resources, these standards were challenging to enforce.

The Trust closed indoor facilities, closed park gates at times of high virus alerts and curtailed vehicle access, but pedestrian access to the park remained open as it was felt that this was needed more than ever during the pandemic. As alert levels fell, access to the park was increased. External gates were opened allowing the whole community to access the park again.

The park was more frequently visited, especially by city locals. It also experienced a high number of new visitors that had the time and the desire to get outdoors, exercise and experience nature; these new visitors may become more regular users.

The park's funding is predominantly from lease revenue from adjacent properties. Responding to the economic uncertainty about these revenues, the Trust implemented various budgetary measures and contingency plans. A more constrained COVID-oriented budget may result in more modest park aspirations, fewer park capital and repair projects, and less confidence in financial forecasting.

Innovations and lessons: Because changing pandemic alert levels required different management responses, public communication to park visitors was critical. The park capitalised on its online following using branded designs on its website and Facebook and Instagram channels, leading to more followers and views.

Park staff also tested ways of encouraging visitors to experience the park without cars - providing space to allow greater social distancing. The result: more families with small children were riding bikes and scooters in a larger and safer space. Many visitors supported the concept of road closures with more space for walkers and cyclists. Park management got a better indication of the number of people who would walk to the park rather than drive. This more pedestriancentred approach will be a lesson for future park planning.

\section{Snapshot 9: Alameda and Contra Costa County, California - East Bay Regional Park District and Los Angeles and Ventura County, California - Santa Monica Mountains Conservancy zone and National Recreation Area ${ }^{10}$}

Partnerships across public parks and public health

\begin{abstract}
"Our decade of experience with the Park District's Healthy Parks Healthy People program was a game changer when the pandemic hit. Because of that program, we had deep and trusted relationships with public health officials, and we could turn to these experts for their amazing expertise, guidance, and assistance. With their help, we were able to act quickly and effectively."
\end{abstract}

Robert Doyle, General Manager, East Bay Regional Park District

East Bay Regional Park District and the Santa Monica Mountains Conservancy zone: Two of the world's largest and most visited systems of urban parks and protected areas with parks on the doorstep of urban and suburban residents, ranging up to 50 kilometres from city centres.

Impacts and challenges: East Bay Regional Park District (EBRPD) closed their parks for an initial 24 hours but thereafter were able to keep 99 per cent of outdoor sites open and accessible. The County health department determined that the East Bay parks were 'essential services', allowing them to remain open, provided the

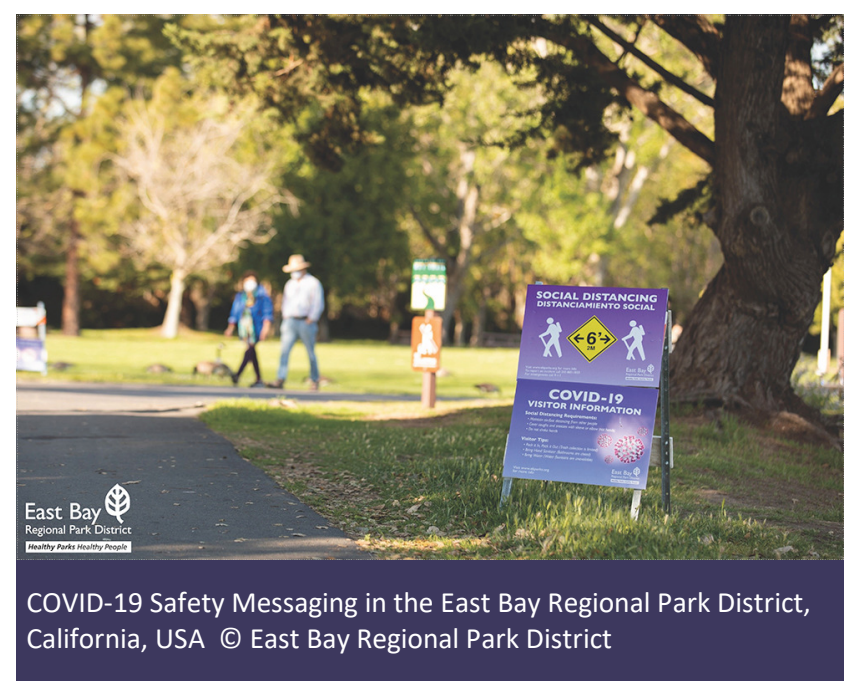


right public health measures were in place. Since reopening, park visitation has increased more than 50 per cent with many first-time visitors.

Across the Santa Monica Mountains, various park closures were implemented in March 2020, especially in places that attracted large numbers of visitors. They remained closed until May 2020. US National Park Service (NPS) and Santa Monica Mountains Conservancy staff worked with county health departments to develop a pandemic plan. Since the park has more than 300 points of entry, managing visitor access has been a challenge, but visitation is also dispersed. Once trails were opened, the Los Angeles County Parks Department oversaw coordination between local, state and federal entities.

Because the Santa Monica Mountains Conservancy relies heavily on income generated by park visits, events and concessions, the economic impacts of the pandemic have been extremely significant. A 66 per cent loss of Conservancy revenue to fund park operations has led to staff reductions, furloughs and reduced services.

Lessons and innovations: Robert Doyle, General Manager of EBRPD, attributes the ability to quickly open its parks - and keep them open - to its close working relationship and trust with public health officials and doctors. A recently commissioned EBRPD survey revealed that 96 per cent of East Bay respondents believe that accessibility to parks and trails has been significant in maintaining the mental and

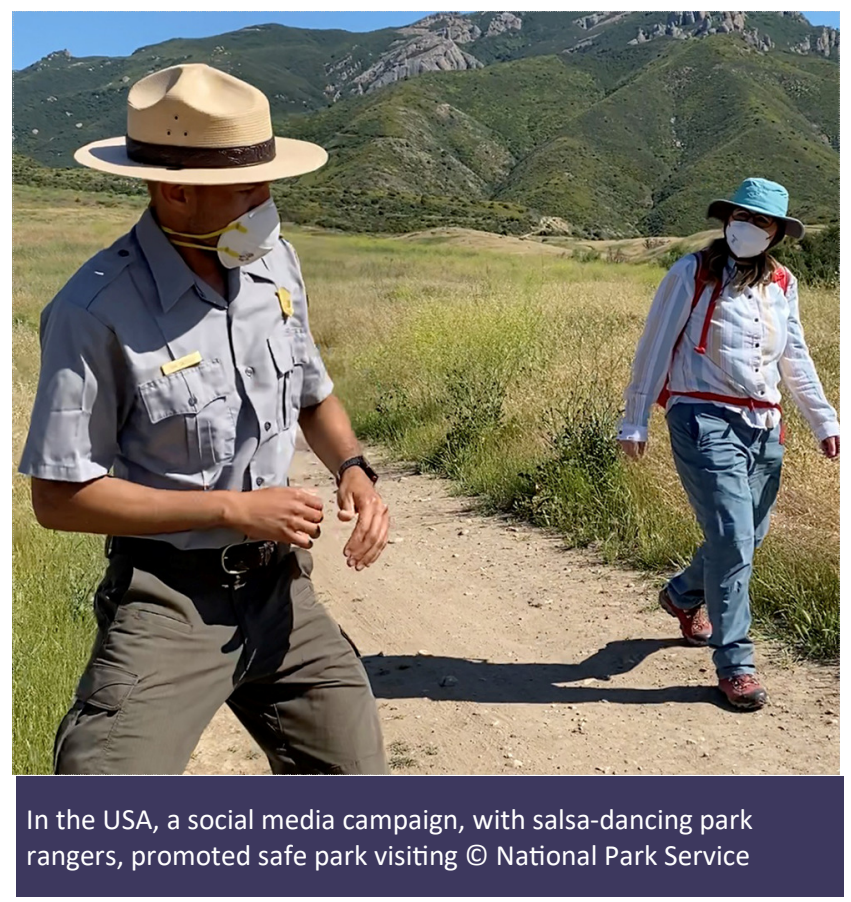

physical health of East Bay communities during the pandemic; 94 per cent of first-time visitors said they would visit the parks again.

In the Santa Monica Mountains, the NPS responded to the pandemic by adopting virtual programming, producing 72 park programmes with almost 250,000 views. The NPS also launched a creative social media campaign encouraging park visitors to wear face masks and social distance in the parks.

As a result of the coordination among park agencies because of the pandemic, new conversations about the future are occurring, including about more equitable access to recreation. The Santa Monica Mountains Conservancy is considering a new revenue model based on a pilot 'taxing district' to fund efforts to combat wildfire insecurity as well as more general park needs.

\section{INNOVATIONS}

Given the dynamic and pressing nature of the pandemic, some parks still found time to innovate during this major and unexpected crisis. Most innovations involved communications with the public, safely managing visitation and enhancing partnerships.

Various park areas found new ways to reach the public with technology playing a major role. East Bay Regional Park District launched a public communications campaign in traditional media outlets and through social media. The NPS at Santa Monica Mountains launched a social media campaign encouraging maskwearing with salsa dancing rangers. ${ }^{14}$ Almost all parks moved to virtual programming and communications with many using social media platforms to new levels of success.

Some park managers were creative and innovative in managing visitors prior to their park visit. Parquemet in Santiago, Chile, and the British Columbia Parks Foundation developed online portals where people could see real-time use of parks, decide to visit a less crowded park site, and even make a reservation for a particular time. Such portals have much potential for managing visitor levels and mitigating overcrowding in urban parks and protected areas, not only during a pandemic but for future park management.

Most parks made changes in access arrangements to promote social distancing. Some parks closed vehicle entrances, parking areas or roads to better control park use and dedicated closed roads as pedestrian and bicycle corridors. Many parks extended the width of trails and converted these walking paths into one-way access 
routes. A golf course in the Presidio of the Golden Gate National Recreation Area was temporarily converted to a large public green space for visitors. Many parks used demarcations to promote social distancing, including the very inventive artistic innovations at Santiago Metropolitan Park. Such innovations may now encourage a deeper look at how parks are affected by car use and how park spaces might be planned in the future.

Stronger partnerships also emerged, especially between park areas and public health officials. Parks with existing health-based partnerships, such as East Bay Regional Park District, were more able to secure the expertise, resources and support to face the pandemic. The Park District helped launch a regular webinar series, hosted by public health officials, hospitals and doctors, to support all San Francisco Bay Area park agencies in developing well-informed and ongoing responses to COVID. ${ }^{15}$ The NATURVATION project (Almassy et al., 2020) recently examined over 500 initiatives in urban parks, gardens and protected areas world-wide, and found 'health and well-being' issues were among the top three sustainability challenges being addressed by parks.

\section{THE FUTURE}

We believe the following trends and lessons learnt during the pandemic are especially relevant to the future of urban parks and management.

Lingering financial impacts: Many park managers are worried, even pessimistic, about the future. Most will face funding reductions and there is great uncertainty about future trends in the economy, travel and tourism and government funding. A report on financial impacts (Trust for Public Land, Parks and the Pandemic, 2020) summarised matters: "The consensus....is that the picture for parks will be bleak indeed."

Greater awareness of parks and their relevance: The pandemic put many urban parks and protected areas at the forefront of the public's mind, with greater media coverage and more visitors. Many surveys documented the public's growing recognition that parks and protected areas are important community, civic, health and economic assets. A national survey in the United States during the pandemic (LaPlaca Cohen, Culture Track and Sloverlinett, 2020) asked people: "What do you want more of in your life right now?" The top answer was "getting outdoors". An article on the impact of COVID-19 on public space (Honey-Rosés et al., 2020) suggested that the pandemic may "transform our relationship with public space" and asked "optimistically, will this global experience lead us to rethink the way we develop and (re)design our cities?" Other indications "highlight that access to urban nature is important to urban resilience in the short- and longterm" (Samuelsson et al., 2020). For park managers, these are hopeful questions and responses.

New audiences to the parks: In most parks, there were new audiences coming to visit. In many cities, the pandemic motivated people to seek the benefits of the outdoors and nature. In some cases, local visitors filled parks that once mainly served national or international visitors. More young people and local people discovered what parks offered; many have been exposed to nature for perhaps the first time in their lives. If the profile of future park visitors changes, it has implications for the level of public support, local advocacy and funding.

Equity in park access and benefits: In many cities, the pandemic highlighted inequitable access to medical treatment and disproportionate rates of infection in poorer communities. This 'equity lens' affected park managers and their perspectives. The Trust for Public Land (2020) reported that 100 million people in the United States do not have a park within a 10-minute walk from home. In many cities, wealthier communities have more access to parks and the outdoors than poorer ones. A study of green spaces during COVID-19 completed by Urban Systems Lab (Lopez et al., 2020) identified these inequities and advocated "reframing urban parks and open spaces as a form of critical urban infrastructure to leverage the multiple health, social, economic, and environmental benefits they provide". The pandemic has reinforced a growing discussion among park managers and the public on whether urban parks and protected areas provide benefits equitably and, if not, what should be done about it. This dialogue - and the actions it may propel - might be one of the positive things that could come from this global tragedy.

\section{HOPE ILLUMINATED}

COVID-19 shone a light on our global community where the health of nature and people are intertwined across borders and continents. On 18 March 2020, demonstrating the international nature of the pandemic, the iconic Christ the Redeemer statue in Tijuca National Park in Rio de Janeiro was illuminated with all the flags of countries affected by the pandemic. The challenges for our parks and nature are global in scope - and the pandemic reminds us of our common plight and shared hopes for the future.

\section{ENDNOTES}

${ }^{1}$ NATURVATON: Link: https://www.naturvation.eu/home

${ }^{2}$ Andrew Day, CEO, British Columbia Parks Foundation: Provided 
information on case study form, by email exchange, review of written materials and phone conversations for the Vancouver Parks Snapshot.

${ }^{3}$ Martín Andrade Ruiz-Tagle, Director, Parque Metropolitano de Santiago: Provided information on case study form, by email exchange, and review of written materials for the Metropolitan Park of Santiago Snapshot.

${ }^{4} \mathrm{Dr}$ Wong Fook-yee, Adjunct Professor, Geography and Resource Management Department, Chinese University of Hong Kong: Provided information on case study form, by email exchange, and review of written materials for the Hong Kong Country Parks and Protected Areas Snapshot.

${ }^{5}$ Lih-Der Ho, Professor, National Kaohsiung Normal University, Taiwan: Provided information on case study form, by email exchange, and review of written materials for the Shoushan National Natural Park Snapshot.

${ }^{6}$ Pedro da Cunha e Menezes, Member, IUCN Urban Conservation Strategies Specialist Group: Provided information on case study form, by email exchange, virtual meeting, and review of written materials for the Snapshot on urban parks and protected areas in Quito Ecuador and Rio de Janeiro, Brazil.

${ }^{7}$ Andrea Minkwe, Manager of Arboretum Raponda Walker protected area and Nelly Houtsa, Environmental lawyer and IUCN World Commission on Protected Areas Youth Professionals focal point in West and South Africa: Provided information on case study form, by email exchange, and review of written materials for the Arboretum Raponda Walker protected area Snapshot.

${ }^{8}$ Shardul Bajikar, consultant and naturalist associated with Sanjay Gandhi National Park: Provided information on case study form, by email exchange, and review of written materials for Sanjay Gandhi National Park Snapshot.

${ }^{9}$ Michael Ayrton, Park Director, Cornwall Park Trust Board: Provided information on case study form, by email exchange, and review of written materials for the Cornwall Park Snapshot.

${ }^{10}$ Robert Doyle, General Manager, East Bay Regional Park District: Provided information on case study form, by email exchange, telephone conversation, and review of written materials for the Urban Protected Areas, California Snapshot.

${ }^{11}$ Joseph T. Edmiston, Executive Director. Santa Monica Mountains Conservancy: Provided information on case study form, by email exchange, virtual meeting, and review of written materials for the Urban Protected Areas, California Snapshot.

${ }^{12}$ David Szymanski, Superintendent, Santa Monica National Recreation Area: Provided information on case study form, by email exchange, virtual meeting, and review of written materials for the Urban Protected Areas, California Snapshot.

${ }^{13}$ National Park Service Video/Social Media Campaign at Santa Monica Mountains Santa Monica Face Mask Video

${ }^{14}$ UCSF and East Bay Regional Park District: Webinar Series Guidance for Parks as an Essential Service During a Pandemic Links below:

https://www.youtube.com/watch?v=8XzMVTn80r0

https://www.youtube.com/watch?v=b3des27YDFk

https://www.youtube.com/watch?v=KU_g1jtY5bw

\section{ACKNOWLEDGMENTS}

The authors acknowledge the assistance that they received from Russell Galt, Head of IUCN Urban
Alliance; Ted Trzyna, Chair, IUCN WCPA Urban Conservation Strategies Specialist Group; Dr. Harriet Bulkeley, Professor, Department of Geography, Durham University, United Kingdom; Neil McCarthy, Chief Executive Officer, World Urban Parks Organisation and Dr. Robert McDonald, Lead Scientist for the NatureBased Solutions, the Nature Conservancy.

Those who contributed towards the preparation of the snapshots are listed in the endnotes.

\section{ABOUT THE AUTHORS}

Greg Moore is CEO Emeritus \& Special Advisor, Golden Gate National Parks Conservancy and a parks/ conservation consultant. Greg has four decades of experience with national parks and protected areas. As the founding CEO of the Parks Conservancy, he grew this organisation to one of the country's most successful partners to the US National Park Service. During his career, he has advised conservation projects in Australia, Canada, Chile, China, Italy, New Zealand, and South Africa. He is a consultant to various international efforts including the Lincoln Institute of Land Policy's International Land Conservation Network and Amigos de Los Parques in Patagonia, Chile.

Jo Hopkins is Chair of the IUCN WCPA Health and Well-being Specialist Group. Jo has extensive experience in protected area management - and is passionate about the health benefits derived from nature. She was part of the team that established the Healthy Parks Healthy People initiative and has continued that work for over 20 years. Jo collaborates with individuals and organisations to influence local, national, and international policy promoting parks as a nature-based solution to the world's most pressing challenges.

\section{REFERENCES}

Almassy, D., Maia, S., Xie, I. and Bulkeley, H. (2020), Naturvation Project Team, personal communication, www.naturvation.eu

Honey-Rosés, J., Anguelovski, I., Chireh, K., Daher, C., Konijnendijk van den Bosch, C., Litt, J., Mawani, V., McCall, M., Orellana, A., Oscilowicz, E., Sánchez, U., Senbel, M., Tan, X., Villagomez, E., Zapata, O. and Nieuwenhuijsen, M. (2020). The impact of COVID-19 on public space: an early review of the emerging questions - design, perceptions and inequities, Cities \& Health, DOI: 10.1080/23748834.2020.1780074 https:// doi.org/10.1080/23748834.2020.1780074

Nishiura, H., Kobayashi, T., Saito, T., Sunagawa, T., Matsui, T., Wakita, T., MHLW COVID-19 Response Team, Suzuki, M. (2020). Closed environments facilitate secondary transmission of coronavirus disease 19) https:// doi.org/10.1101/2020.02.28.20029272 
LaPlaca Cohen, Culture Track \& Sloverlinett Audience Research (2020). Culture + Community in a Time of Crisis. https:// culturetrack.com/research/covidstudy/

Lopez, B., Kennedy, C. and McPhearson, T. (2020). Parks are Critical Urban Infrastructure: Perception and Use of Urban Green Spaces in NYC during COVID-19. Preprints 2020, 2020080620 (doi: 10.20944/preprints202008.0620.v1). http:// urbansystemslab.com/urban-parks-survey

Samuelsson, K., Barthel, S., Colding, J., Macassa, G. and Giusti, M. (2020). Urban Nature as a source of resilience during social distancing amidst the coronavirus pandemic https:// www.stockholmresilience.org/publications/artiklar/2020-05-10 -urban-nature-as-a-source-of-resilience-during-socialdistancing-amidst-the-coronavirus-pandemic.html
Townsend, M., Henderson-Wilson, C., Warner, E. and Weiss, L. (2015). Healthy Parks Healthy People: the state of the evidence review 2015. https://www.iucn.org/sites/dev/files/ content/documents/hphpstate-evidence2015.pdf

Trust for Public Land (2020). A Trust for Public Land Special Report: Parks and the Pandemic. https://www.tpl.org/sites/ default/files/Parks\%20and\%20Pandemic\%20-\%20TPL\% 20special\%20report.pdf

\section{RESUMEN}

Los parques urbanos y las áreas protegidas son vitales para la salud y el bienestar de millones de habitantes urbanos en todo el mundo. La pandemia del COVID-19 ha puesto de manifiesto el carácter apremiante de esta relación en las grandes ciudades donde habita la mayor parte de la población mundial. Los administradores de parques urbanos y áreas protegidas (espacios verdes en los grandes centros de población urbana o en sus bordes) han estado al frente de esta crisis internacional de salud pública desde su inicio, haciendo frente a sus desafíos y repercusiones, adoptando y adaptando las respuestas de los parques y poniendo a prueba nuevos enfoques. PPara fundamentar este artículo, se realizaron encuestas para recopilar las experiencias de los parques urbanos y las áreas protegidas en 11 grandes ciudades en 10 países diferentes. Las conclusiones muestran que los parques urbanos fueron cerrados y al reabrirlos se desbordaron, y que los administradores se enfrentaron a situaciones nuevas y a veces inmanejables. Sin embargo, la mayoría de ellos fueron receptivos y ágiles, se comprometieron con los funcionarios de salud pública, se ocuparon de los nuevos niveles en el número de visitas y de nuevos visitantes, aplicaron prácticas innovadoras de gestión y generaron importantes enseñanzas para el futuro. Si bien persisten enormes retos, hay señales esperanzadoras de una renovada conciencia pública y de apoyo al papel fundamental que la naturaleza y las actividades al aire libre desempeñan en la habitabilidad y la salud de las ciudades.

\section{RÉSUMÉ}

Les parcs urbains et les aires protégées sont cruciaux pour la santé et le bien-être de millions de citadins à travers le monde. L'importance de ce lien a été mise en évidence de façon urgente par la pandémie de COVID-19 dans les grandes villes où vit la majeure partie de la population mondiale. Les gestionnaires d'aires protégées et de parcs urbains (espaces verts dans, ou à la périphérie, des grands centres urbains) sont à l'avant-garde de cette crise de santé publique internationale depuis son apparition - ils font face à ces défis et ces impacts, adoptent et adaptent les réponses du parc et testent de nouvelles approches. Pour éclairer le present document, des enquêtes ont été menées auprès de parcs urbains et d'aires protégées dans 11 grandes villes, dans 10 pays différents, afin de recueillir leurs expériences. Les résultats montrent que les parcs urbains ont été fermés, puis souvent débordés lors de leur réouverture, et que les gestionnaires ont été confrontés à des situations nouvelles et parfois ingérables. Cependant, la plupart se sont montrés réactifs et agiles, ont collaboré avec les responsables de la santé publique, se sont adaptés aux nouvelles jauges de visites et aux nouveaux visiteurs, ont mis en œuvre des pratiques de gestion innovantes et ont tiré des leçons pour l'avenir. D'énormes défis demeurent, mais il y a des signes encourageants d'une prise de conscience et d'un soutien renouvelé du public pour le rôle essentiel que jouent la nature et le plein-air dans la qualité de vie et la santé des villes. 